DOI: $10.11649 /$ abs.2018.003

\title{
Walentyna Krupowies
}

Uniwersytet Przyrodniczo-Humanistyczny w Siedlcach vakru@onet.eu

\section{Rok 1919: pamięć Wilna - pamięć w Wilnie}

Badania nad pamięcią nie tyle jako zdolnością osobniczą, ale przede wszystkim jako złożonym fenomenem kulturowym i społecznym doprowadziły do wyodrębnienia przez współczesną humanistykę kilku jej form. I chociaż każda $\mathrm{z}$ form pamięci obejmuje inny zakres czasowy i przestrzenny, każdy ze sposobów pamiętania posługuje się odmiennym medium, to nie tworzą one zamkniętych struktur. Można je raczej porównać do amfiladowego rozkładu pokoi ${ }^{1}$, który to układ umożliwia swobodne przemieszczanie się treści pamięci. Wśród wyodrębnionych form pamiętania ważną triadę tworzą pamięć indywidualna - komunikacyjna - kulturowa, wielostronnie analizowaną na gruncie współczesnej humanistyki². Te trzy rodzaje pamięci ujmowane w ścisłym wzajemnym splocie pozwalają nie tylko śledzić wymianę treści pamięci, ich wędrówkę od poziomu indywidualnego do kulturowego, dostrzec społeczne i kulturowe ramy pamięci osobniczej ${ }^{3}$, ale także przekonać się, że ich cyrkulacja „pracuje” na rzecz budowania i podtrzymywania indywidualnej i zbiorowej tożsamości.

\footnotetext{
${ }^{1}$ Przestrzenne metafory, które miały pomóc zrozumieć fenomen pamięci, pojawiły się już w starożytności, mają więc bardzo długą tradycję. W kulturze europejskiej najtrwalej zapisały się znajdujące się w dziełach Platona oraz stosowane przez św. Augustyna (por. Rosińska, 2006, ss. 263-278).

${ }^{2}$ Szereg ważnych ustaleń dotyczących funkcjonowania pamięci komunikacyjnej i kulturowej poczynili badacze niemieccy. Koncepcje te zostały omówione przez M. Saryusz-Wolską (Saryusz-Wolska, 2009).

${ }^{3}$ Teza, iż pamięć indywidualna funkcjonuje w społecznych ramach, została sformułowana w pionierskiej pracy M. Halbwachsa Społeczne ramy pamięci (Halbwachs, 2008).
}

This is an Open Access article distributed under the terms of the Creative Commons Attribution 3.0 PL License (creativecommons.org/licenses/by/3.0/pl/), which permits redistribution, commercial and non-commercial, provided that the article is properly cited. () The Author(s) 2018. 


\section{Jak pamięta wspólnota? (perspektywa polska)}

Sądzę, iż przywołane powyżej ustalenia współczesnych badań nad pamięcią czy krążeniem treści pamięci pomiędzy różnymi jej poziomami mają walor uniwersalnych narzędzi badawczych, poręcznych w opisywaniu poszczególnych wspólnot pamiętających. Warto więc je odnieść do konkretnej wspólnoty, znajdującej się w przełomowym momencie historycznym, kiedy to wymiana treści różnych form pamięci nabiera przyspieszenia. Taką wspólnotę tworzyła m.in. polska społeczność w Wilnie 1919 roku.

Funkcjonowanie trzech form pamięci jako płynnej jedności ujawniło się na gruncie kultury wileńskiej w określonym czasie historycznym, a mianowicie w okresie intensywnych przygotowań do reaktywacji uniwersytetu i uroczystego otwarcia uczelni, czyli od wiosny do jesieni 1919 roku.

Od czasu zamknięcia Uniwersytetu Wileńskiego starania o jego reaktywowanie były podejmowane wielokrotnie, $\mathrm{w}$ tym również $\mathrm{w}$ wieku dziewiętnastym ${ }^{4}$. Sposobny czas dla takich inicjatyw nastał jednak dopiero w roku rewolucyjnego wrzenia. W grudniu 1905 roku powstało „Towarzystwo popierania założenia wolnego uniwersytetu w Wilnie". Inicjatywie przewodniczył profesor uniwersytetu w Petersburgu Jan Baudouin de Courtenay. Nie doszła ona do skutku przede wszystkim z powodu braku odpowiednich kadr naukowych w Wilnie ${ }^{5}$.

Po opuszczeniu Wilna przez Rosjan oraz wkroczeniu wojsk niemieckich miasto znalazło się w odmienionej rzeczywistości politycznej. Pierwsza odezwa nowych władz okupacyjnych, określająca Wilno jako „perłę Korony Polskiej”, mogła napawać optymizmem polską społeczność miasta. Na przełomie roku 1915/1916 podjęto więc kolejne starania o odbudowę uniwersytetu, jednak zgody na urzeczywistnienie projektu nie uzyskano (Wrzosek, 1929, s. 3).

Idea uniwersytetu w Wilnie nabrała konkretnych kształtów jesienią 1918 roku'. W tym okresie dużą aktywnością odznaczała się strona litewska. Za zgodą władz niemieckich i pod auspicjami Litewskiej Rady Państwa (Taryby) został opracowany statut przyszłej państwowej uczelni w Wilnie, zakładający jej uruchomienie już 1 stycznia

${ }^{4}$ Dziewiętnastowieczne próby uzyskania pozwolenia na reaktywację wszechnicy wileńskiej przywołuje w Księdze Pamiątkowej Adam Wrzosek. Pierwszą próbę podjął marszałek szlachty guberni wileńskiej Edward Mostowski w roku 1843. Po raz drugi prośba o wskrzeszenie uniwersytetu została wystosowana w 1858 roku do cara Aleksandra II przez marszałka szlachty Kaliksta Orzeszko (Wrzosek, 1929, ss. 1-2).

${ }^{5} \mathrm{~W}$ starania o odrodzenie uniwersytetu było zaangażowane środowisko „Kuriera Litewskiego”. Szerzej na ten temat pisał Andrzej Romanowski (Romanowski, 1999, s. 63).

${ }^{6}$ Dokładną rekonstrukcję przebiegu zdarzeń związanych z wskrzeszeniem uniwersytetu w Wilnie w latach 1918-1919 w kontekście wielkiej polityki, osobistego zaangażowania Piłsudskiego, a także rozgrywek ambicjonalnych między środowiskiem polskim w Wilnie a warszawskim Ministerstwem Wyznań Religijnych i Oświecenia Publicznego przeprowadziła Danuta Zamojska (zob. Zamojska, 2006, zwłaszcza ss. 8-22). 
1919 roku (Jegelevičius, 1994, ss. 45-46). W tej sytuacji strona polska przyspieszyła prace nad odbudową uniwersytetu. W Warszawie 13 grudnia podczas obrad tzw. Komisji Litewskiej we współpracy z Komitetem Polskim w Wilnie podjęto stosowną uchwałę a datę powstania uczelni wyznaczono najpóźniej na jesień 1919 roku.

Rok 1919 przyniósł zwycięstwo koncepcji wypracowywanej w środowisku polskiej inteligencjī Wiąże się ono ściśle z ówczesnymi wydarzeniami: wkroczeniem wojsk polskich do Wilna w kwietniu 1919 roku oraz ustanowieniem administracji podlegającej Zarządowi Cywilnemu Ziem Wschodnich. Powstał polityczny grunt, bezwzględnie potrzebny, by idei uniwersytetu w Wilnie, zakorzenionej w sferze pamięci kulturowej i wspomaganej pamięcią rodzinną, nadać instytucjonalny kształt.

W okresie od wiosny do jesieni 1919 roku podjęto szereg działań zapoczątkowujących proces scalania treści pamięci kulturowej, wspomaganych przez pamięć rodzinną $\mathrm{i}$ indywidualną, $\mathrm{z}$ odzyskanym miastem. Pilnym zadaniem było przywrócenie jedności między historyczną i kulturową tradycją miasta a jego rzeczywistym stanem. W zachowany w dużej mierze układ urbanistyczny, architekturę należało „wpisać” wyrugowane formy upamiętnienia: toponimy, pomniki, tablice itp., a także przenieść do sfery publicznej przechowywane w ukryciu materialne ślady przeszłości, które uzyskały status pamiątek i wyjątkowych świadectw, jak również zintensyfikować poszukiwanie wszelkich śladów dawności. Jednak najważniejszą sprawą było wskrzeszenie uniwersytetu, albowiem odrodzony uniwersytet, zarówno jako idea i uczelnia, jak i zespół gmachów usytuowanych w przestrzeni Wilna, reprezentował najważniejszą część kulturowo-tożsamościowej imagologii polskiej inteligencji ${ }^{8}$, czyli

${ }^{7}$ Należy przywołać jeszcze jedną inicjatywę budowania uniwersytetu w 1919 roku: w zajętym przez bolszewików Wilnie w dniu 13 marca 1919 roku Rada Komisarzy Ludowych Litwy i Białorusi ogłosiła dekret o „utworzeniu w gmachu dawnego Uniwersytetu Wileńskiego - »Powszechnego Uniwersytetu Pracy« mającego się składać z trzech działów: ogólnokształcącego, naukowego i specjalnego". Zajęcia miały się odbywać „w językach krajowych” (Ruszczyc, 1994, s. 359).

${ }^{8}$ Należy wspomnieć o zróżnicowaniu światopoglądowym, ideowym, politycznym inteligencji wileńskiej. Poza tym zamieszkiwała ona miasto wielokulturowe i wielonarodowe, co rodziło tożsamościowe dylematy. Z dzisiejszego punktu widzenia może najciekawszą koncepcję tożsamości kulturowo-politycznej mieszkańców dawnego Wielkiego Księstwa Litewskiego (dalej WXL) sformułowano w gronie osób o poglądach demokratycznych, którzy nazwali siebie krajowcami. „Idea krajowa” zrodziła się z poczucia odrębności, z potrzeby - jak pisał jeden z jej zdecydowanych zwolenników - „pewnego ideowego scalenia tego wszystkiego, co stanowiło obszar różnolity pod względem etnicznym i wyznaniowym, ale jednolity w związaniu terytorialnym, kulturalnym i wspólnego historycznego bytu" (Jundziłł, 1958, s. 46). Krajowcy byli też zwolennikami federalistycznej koncepcji Józefa Piłsudskiego. I chociaż wiosną 1919 roku uczestnicy wydarzeń mogli sądzić, iż koncepcja się urzeczywistni (prowadzono m.in. nieformalne rozmowy o utworzeniu rządu w Wilnie złożonego z przedstawicieli różnych narodowości; Römer, 2018, ss. 691-698), to dzisiaj wiemy, że Zeitgeist podążał innym traktem. Zwyciężyła idea etniczności i opowiedzenie się po którejś ze stron stało się koniecznością. Większość wileńskich krajowców wybrała polską państwowość, jednak były osoby, które zadecydowały inaczej. Za modelowy przypadek może tu służyć decyzja Michała Römera o przeniesieniu się do Kowna, równoznaczna z opowiedzeniem się za litewskością. Po latach 
wileńską tradycję oświeceniowo-klasycystyczną, intelektualny ferment filomacko-filarecki jako ideowe podłoże dla polskiego romantyzmu, potężne władztwo Mickiewicza nad zbiorową wyobraźnią.

Rok 1919 - to czas, gdy nie ma już uczestników i świadków działalności uniwersytetu sprzed jego zamknięcia przez władze carskie, zatem w procesie odbudowywania zerwanej ciągłości nie można było się oprzeć na niezapośredniczonej pamięci osobniczej, na obecności uczestników czy chociaż obserwatorów ówczesnego życia uniwersyteckiego oraz ich opowieści. Indywidualna pamięć świadków wygasła9. Żywa natomiast była pamięć indywidualna dwu-trzech pokoleń mężczyzn uczęszczających w swoim czasie do męskiego gimnazjum, mieszczącego się w uniwersyteckich budynkach. Ich pamiętanie zostało naznaczone poczuciem utraty, braku, zerwania, bólu z powodu nieuczestniczenia. Ten sposób pamiętania określa przede wszystkim zasada negatywności. Ujawniła się ona na przykład w przemówieniu Piłsudskiego:

[...] mury te widziały i gorsze czasy, czasy nieszczęścia, w których i ja byłem małym, nieznacznym aktorem. Była to wówczas także uczelnia, lecz na niej widniał groźny napis: Vae victis - Biada zwyciężonym. A tymi zwyciężonymi były małe dzieci lub podrastający młodzieńcy („Przemówienie Naczelnika Państwa podczas otwarcia Uniwersytetu”, 1919, s. 1).

Do tego pokolenia należał też Jan Bułhak, który w ten sposób wspominał swoje towarzyszenie Ferdynandowi Ruszczycowi podczas rekonesansu uniwersyteckich gmachów:

[...] idę z nim do murów uniwersyteckich. [...] A tam już odbywa się czyszczenie Augiaszowych stajen moskiewskich. [...] Ja, który w nich przebywałem tyle lat $\mathrm{w}$ gimnazjum rosyjskiem, odnajduję znajome miejsca, sale szkolne, nawet „karcer”, w którym nas zamykano za rozmowę po polsku (Bułhak, 1939, s. 189).

na emigracji jego dawny ideowy przyjaciel wybór ten skomentował w następujący sposób: „[Michał Römer] [...] staje się Litwinem i od 1920 roku reprezentuje już wąskie interesy państwowości litewskiej" (Jundziłł, 1958, s. 43).

Refleksja nad tożsamością polskiej inteligencji w Wilnie mogłaby koncentrować się na analizie związku między ziemiańskim pochodzeniem wielu jej przedstawicieli a Wilnem wyobrażonym, kształtowanym przez różnorakie teksty przezeń tworzone. Jest to jednak temat na inne studium.

[Powyższe rozważania powstały z inspiracji Recenzenta niniejszego artykułu, za co autorka składa serdeczne podziękowanie].

${ }^{9}$ Ludwik Janowski, dziekan Wydziału Humanistycznego, z dużym żalem mówił w swoim wykładzie: „Ze znamienitej plejady Wileńczyków, profesorów i wychowańców, dnia tego nie doczekał ani jeden. Do końca ubiegłego stulecia pozostawało przy życiu dwu profesorów: chemik Ignacy Fonberg (1891) i matematyk Z. Rewkowski (zm. 1894). Żyło jeszcze dłużej paru uczniów: Franciszek Nowicki (1903), Dowgiałło (1914), Szczęsny Korwin-Piotrowski (1916). [Z ich śmiercią] ostatnie żywe ogniwa z tamtą epoką znikły" (Janowski, 1929, s. 25). 
Natomiast czynna jeszcze była pamięć komunikacyjna ${ }^{10} \mathrm{i}$ może najważniejsza jej postać - pamięć rodzinna ${ }^{11}$. Dlatego też przeszłość wileńskiego uniwersytetu nie była li tylko obiektem zamkniętym w bibliotekach, archiwach, muzeach, ale odsłaniała się dzięki ustnym opowieściom, zapiskom, wspomnieniom, będących w posiadaniu kolejnych pokoleń, czyli funkcjonujących w obrębie kulturotwórczych rodzin wileńskich. Zgodnie z mechanizmem funkcjonowania przywoływanej tu triady, zasoby pamięci rodzinnej zazwyczaj uzupełniają kulturową tradycję zbiorowości, a sama pamięć rodzinna powoli wygasa ${ }^{12}$. Przenoszenie jej treści do zasobów pamięci kulturowej nie przebiega równomiernie, tylko w pewnym momencie, zazwyczaj w trzecim i czwartym pokoleniu, nabiera przyspieszenia. Na gruncie kultury wileńskiej za znamienny pod tym względem należy uznać rok 1919.

A więc, tradycja uniwersytecka w Wilnie na poziomie żywej pamięci indywidualnej funkcjonuje w tym czasie jako brak, utrata powodująca ból o znamionach traumy, natomiast na poziomach komunikacyjnym i kulturowym funkcjonuje jako fundament wspólnotowej tożsamości. Ich współdziałanie odegrało też zasadniczą rolę podczas wskrzeszania uczelni.

Skomplikowany proces współpracy różnych form pamięci, nazywany „cyrkulacją pamięci”, zapewnia transmisję jej treści w czasie. W sytuacji braku państwowości, przerwanej na wiele pokoleń ciągłości politycznej, niemożności symbolicznego uobecniania własnej przeszłości w przestrzeni publicznej, ciągłość tradycji podtrzymywała wymieniona powyżej triada. Po odzyskaniu niepodległości stała się ona symboliczno-ideowym zapleczem dla budowanych instytucji nauki i kultury w Wilnie, zwłaszcza dla wskrzeszanego uniwersytetu. Kilkudziesięcioletnia przerwa w jego działalności wymagała wielu zabiegów stricte organizacyjnych: znalezienia i zaangażowania kadry naukowej, odzyskania i remontu budynków, odbudowania zerwanej ciągłości życia naukowego, zapoczątkowania procesu nauczania itp. Większości tych działań podjęły się osoby pozostające w kręgu wileńskiej pamięci

${ }^{10}$ Polska badaczka „kultury pamięci”, odwołując się do koncepcji rozwijanych na gruncie niemieckim, w ten sposób pisała o pamięci komunikacyjnej: „Koncepcji pamięci komunikacyjnej, według Welzera i Assmanna, wspólny jest zakres czasowy trzech do czterech pokoleń oraz utrwalanie przekazu nie w przestrzeni społeczno-kulturowej, lecz w indywidualnych biografiach” (Saryusz-Wolska, 2009, s. 31).

${ }^{11}$ Prace polskiego badacza pokazują, jak bardzo istotną rolę pamięć rodzinna pełniła w kulturze sarmackiej. Kluczowa pod tym względem jest książka Archiwa sarmackiej pamięci. Funkcje i znaczenie rękopiśmiennych ksiag silva rerum w kulturze Rzeczypospolitej XVIII w. (Roszak, 2004).

${ }^{12}$ Dobrą ilustracją procesu przenoszenia treści pamięci rodzinnej do pamięci kulturowej jest drugi tom Dziennika Ferdynanda Ruszczyca. W znacznej swej części został on ułożony z fragmentów listów malarza do żony Giny Ruszczycowej mieszkającej w rodzinnym majątku Ruszczyców w Bohdanowie, pisanych w latach 1921-1932. Fragmenty te zostały wybrane i ułożone w formie dziennika przez syna malarza. Wydane w 1996 roku „opuściły” sferę prywatną i stały się częścią polskiej i wileńskiej pamięci kulturowej (Ruszczyc, 1996). 
rodzinnej i kulturowej ${ }^{13}$. Należał do nich m.in. Ludwik Janowski, dziekan Wydziału Humanistycznego w latach 1920-1921. Po jego śmierci tak o nim pisała Walentyna Horoszkiewiczówna:

Dzieckiem jeszcze będąc, wsłuchiwał się w domu rodziców swoich w Stawiszczach w rozmowy starszych, przeplatane bardzo często wspomnieniami o Wilnie i Wszechnicy Wileńskiej, opowiadanymi przez p. Rumbowicza, którego ojciec był uczniem Uniwersytetu Wileńskiego. [...]. W gimnazjum zaczyna już poważnie studiować dzieje ukochanej Wszechnicy i gromadzić materiały do swej pierwszej młodzieńczej pracy [...] (Horoszkiewiczówna, 1922, s. 40).

W przywołanym cytacie uwidocznia się współdziałanie dwu form pamięci: żywa pamięć rodzinna zapoczątkowała zainteresowanie uniwersytecką tradycją Wilna i wyznaczyła jeden z kierunków pracy badawczej Janowskiego, która z kolei uzupełniała zasoby zinstytucjonalizowanej pamięci kulturowej. Stanisław Kościałkowski w swoim wykładzie wygłoszonym po śmierci dziekana przywołał opublikowane przezeń prace oraz zebrany materiał i uznał, iż dorobek Janowskiego ,jest bezwzględnie posunięciem wiedzy naszej o uniwersytecie wileńskim naprzód” (Kościałkowski, b.d.).

Do tegoż grona należy też włączyć Ferdynanda Ruszczyca ${ }^{14}$. Można zaryzykować twierdzenie, iż Ruszczyca, inicjującego w swoim czasie życie kulturalne Wilna, zaangażowanego w odrodzenie kultury wileńskiej już od czasu wyjazdu z Krakowa a następnie z dużym poświęceniem działającego na rzecz wskrzeszenia uniwersytetu oraz powstania Wydziału Sztuk Pięknych formowała potęga dwu form pamięci: rodzinnej i kulturowej, co wyraźnie zostało wyartykułowane przez samego artystę w jednym z publicznych odczytów:

Od lat dziecinnych, z opowiadań matki lub może dziada-weterana, z pierwszych - po elementarzu podręczników szkolnych, często przemycanych, każdy z nas zapamiętał, że ze słowem „Wilno" połączone było dla tych starszych jakieś ukrywane wzruszenie, że to słowo wymawiane było z jakimś naciskiem, by zapadło głębiej w pamięci młodej duszy dziecięcej. I pozostawało to Wilno dla nas w późniejszych latach życia czymś jakby mistycznym, czymś związanym z uczuciem i wiarą, [...]. Pragnęliśmy wszyscy, by ono było takim, jakim myśmy je widzieli w naszych wspomnieniach lub snach [...] (Ruszczyc, 1937, s. 93).

Obie formy pamięci przechowywały, utrwalały i przekazywały następnym generacjom wiedzę o przeszłości, przy czym pamięć rodzinna wspomagała proces

${ }^{13}$ W tym czasie działał już, powołany na początku 1919 roku, tymczasowy Senat na czele z Józefem Ziemackim - jednym $\mathrm{z}$ ważnych promotorów idei odbudowana uniwersytetu w Wilnie - oraz Komisja Organizacyjno-Rewindykacyjna, złożona w znacznej mierze z wileńskich działaczy społecznych (Wrzosek, 1929, ss. 6-7; Zamojska, 2006, ss. 9-10).

${ }^{14}$ O roli Ruszczyca w odrodzeniu uniwersytetu pisał m.in. Bułhak (zob. Bułhak, 1939, s. 197). 
interioryzacji treści pamięci kulturowej przez jednostkę. Przeszłość miasta spleciona z przeszłością rodziny stawała się żywą opowieścią, funkcjonującą częściowo w obiegu ustnym, w owych opowieściach „dziada-weterana”, i głęboko nasyconą uczuciową aurą opowiadacza. Tradycja rodzinna jest tu o tyle istotnym ogniwem, ponieważ wraz z wiedzą o przeszłości zostaje przekazany emocjonalny doń stosunek opowiadacza. Wzbogacona emocjonalnością osób najbliższych była tym głębiej i trwalej przyjmowana i uznawana za swoją przez następne pokolenia. Ruszczyc w dalszej części swojej wypowiedzi nadal chętnie posługuje się pierwszą osobą liczby mnogiej. Tym samym odsłania świadomość istnienia pewnej wspólnoty, jak to ujmie, „synów tej ziemi”, której ważnym tożsamościowym filarem jest dziedziczona pamięć o Wilnie, zwłaszcza tradycja uniwersytecka zrośnięta z filomacką i Mickiewiczowską legendą ${ }^{15}$.

$\mathrm{W}$ trakcie przygotowań do otwarcia uniwersytetu, podczas dwudniowych uroczystości, jak również w okresie późniejszym zintensyfikował się proces przenoszenie treści pamięci rodzinnej do sfery publicznej. Znamienne pod tym względem były same uroczystości. Zadbano wówczas, by odnaleźć i zaprosić potomków osób w ten czy inny sposób związanych z uniwersytetem sprzed jego zamknięcia. Najważniejszym gościem w tym gronie był niewątpliwie Władysław Mickiewicz, któremu jeszcze przed oficjalnymi uroczystościami nadano tytuł profesora honorowego Uniwersytetu Stefana Batorego (dalej USB). Przemówienie sędziwego syna Mickiewicza, jego fizyczna obecność były traktowane wręcz jako duchowe uobecnienie samego poety. Z dużą emfazą pisano w ówczesnej prasie: „wyjechał wygnany przemocą, wraca w osobie syna, prowadząc go duchem po mieście swej młodości” („Władysławowi Mickiewiczowi w dniu Jego przyjazdu do Wilna składa w hołdzie Redakcja”, 1919, s. 1). W relacji z dużym wzruszeniem przywoływano obecność córki Andrzeja Towiańskiego: „Śród licznego grona gości [...] powszechną uwagę zwracała postać pochylonej staruszki idącej w pochodzie obok Władysława Mickiewicza. Była to pani Waleria z Towiańskich Kulwieciowa, ostatnia z żyjących dzieci Andrzeja Towiańskiego, ongiś ucznia wydziału prawnego Uniwersytetu Wileńskiego [...]” („Echa uroczystości uniwersyteckich”, 1919, s. 2). Wśród przemawiających znalazł się wnuk Adama Czartoryskiego i jego imiennik

${ }^{15}$ Pamięć komunikacyjna oddziaływała jeszcze na następne pokolenie, które w tym czasie wchodziło $\mathrm{w}$ dorosłe życie. Jego przedstawiciele utworzyli pierwszy rocznik studentów Uniwersytetu Stefana Batorego (dalej USB), a jeden z najbardziej znanych jego reprezentantów, Wiktor Sukiennicki, po latach w swoich wspomnieniach przyznawał, że żywa opowieść kształtowała i jego emocjonalny stosunek do przeszłości, i jego wyobrażenia o uniwersytecie: „W najmłodszym dzieciństwie w Kownie od starego Adama, który z niejednego pieca chleb jadł, [...], słyszałem niekończące się opowieści o Wilnie, o jego cudnych kościołach i, oczywiście, o Uniwersytecie, o profesorach i studentach. [...] ich istnienie wiązało się w naszych umysłach z minionym okresem wielkości i wszelkiej pomyślności; ich brak z obecną biedą i nędzą. Studenci Uniwersytetu, nie mówiąc już o profesorach, zarysowali się w naszej wyobraźni jako jacyś "nad-ludzie«, a Uniwersytet w Wilnie jako panaceum na wszystkie doskwierające nam biedy i kłopoty" (Sukiennicki, 1967, s. 16). 
(„Uroczyste otwarcie uniwersytetu”, 1919, s. 9). Grono zaproszonych potomków było bardziej liczne, a wśród nich - Stanisław Mianowski, prawnuk Mikołaja Mianowskiego, profesora Uniwersytetu Wileńskiego, który po latach wspominał:

[...] doręczył mi pismo rektora Uniwersytetu Wileńskiego - profesora Siedleckiego, zapraszające mnie, jako prawnuka prof. Mikołaja Mianowskiego, na uroczystość wskrzeszenia tego uniwersytetu. [...] dostałem urlop i specjalnym pociągiem udałem się do Wilna. W jednym przedziale ze mną jechali profesorowie [...] i potomek Śniadeckich, młody człowiek o tym nazwisku (Mianowski, 1995, ss. 122-123).

Obecność dzieci, wnuków a nawet prawnuków osób związanych z dawnym uniwersytetem zaspokajało pragnienie kontaktu ze świadkiem przeszłości wspólnoty. Potomkowie występowali tu niejako w zastępstwie swoich przodków. Ich obecność wynikająca $\mathrm{z}$ więzów krwi była widzialnym uobecnieniem przeszłości tu i teraz, wydarzeniem w pełni wspólnotowym, w trakcie którego dokonywał się też publiczny akt przeniesienia treści pamięci rodzinnej do pamięci kulturowej. To w tym dniu Władysław Mickiewicz złożył obietnicę, że „wszystkie pamiątki i dokumenta po Ojcu dotyczące okresu wileńskiego ofiaruje Wszechnicy", natomiast Adam Czartoryski przekazał „wszystkie swe przebogate zbiory naukowe i artystyczne”, („Uroczyste otwarcie uniwersytetu”, 1919, s. 9), z kolei córka Towiańskiego przekazała Uniwersytetowi „na ręce J. M. Rektora piękny portret Andrzeja Towiańskiego pędzla Walentego Wańkowicza z odpowiednim napisem” („Echa uroczystości uniwersyteckich”, 1919, s. 2). Akt przekazywania rodzinnych pamiątek nie tylko wzbogacał materialne zasoby pamięci kulturowej, był też gestem o dużym ładunku symbolicznym, wyznaczał wyraźną cezurę czasową, poza którą pamięć rodzinna, zwłaszcza rodzin kulturotwórczych, w pełni stała się częścią wileńskiej pamięci kulturowej.

Głębokie osadzenie wileńskiej tożsamości w kulturze pamięci sprawiało, iż przeszłość zyskiwała status wyjątkowy również w wymiarze indywidualnym. Ówczesne wypowiedzi, relacje zaświadczają, iż dystans czasowy ulegał radykalnemu skróceniu i przeszłość prawie sprzed stulecia stawała się czymś bliskim, wręcz doświadczanym przez wielu bardzo osobiście, jakby różne warstwy czasu nałożyły się na siebie, by jednocześnie uobecnić się w teraźniejszości. Ówczesne wspólnotowe w znacznej mierze przeżycia wypowiadała Redakcja „Naszego Kraju”, składając hołd Władysławowi Mickiewiczowi: „Wydaje się jakoby czas wszystko niszczący pogubił gdzieś lata, nudne lata niewoli, które wlókł łańcuchem u naszych stóp, wydaje się, że zbliżyły się czasy i oto zaklęciem losu, siwowłosy, o natchnionym spojrzeniu ognistych oczu, wraca cudem na ojczyzny łono Adam Mickiewicz” („Władysławowi Mickiewiczowi w dniu Jego przyjazdu do Wilna składa w hołdzie Redakcja”, 1919, s. 1). Można sądzić, iż nie była to tylko figura retoryczna, lecz wypowiedzenie pewnego doświadczenia, poniekąd pokrewnego opisywanemu przez badaczy historycznych narracji, gdy jednostka doświadcza przeszłości tak, jak w bezpośrednim doznaniu zmysłowym doznaje się 
rzeczywistości (Ankersmit, 2004, s. 223). Ówcześni wilnianie nie zgodziliby się, że świat miniony „to obcy kraj”" . Można powiedzieć, że w ich przypadku doszło do swoistego ścieśnienia kulturowego czasu i powstało silne poczucie, iż żyjący w 1919 roku są bezpośrednimi spadkobiercami pokolenia filomatów ${ }^{17}$.

Intensywne przeżycia angażujące całą gamę emocji nie były li tylko szybko przemijającą eksplozją uczuć. Nadawano im językowy kształt, zostawiły one ślad w dziennikarskich relacjach, dziennikach czy wspomnieniach zapisywanych już z pewnego dystansu czasowego. W swoim Dzienniku, poniekąd „na gorąco”, Władysław Zahorski pod datą 10 października zanotował: „I oto nastały dnie [...], dnie cudu. Przyszłe pokolenia będą nam zazdrościły, żeśmy w tych dniach żyli, żeśmy te cuda widzieli [...]". Również zapis z dnia uroczystego otwarcia uczelni rozpoczyna emfatyczna fraza: „Dzień ten historyczny złotymi zgłoskami zapisze się w dziejach oświaty w naszym kraju" (Zahorski, 1919-1920). Silne uczucia: radości, spełnienia, satysfakcji, dumy, choć przeżywane przez każdego z osobna, miały też charakter wspólnotowy i ponadstanowy. Tę wielką wspólnotową radość po latach wyjaśniał Antoni Gołubiew w 1919 roku uczeń wileńskiego gimnazjum oraz naoczny świadek wydarzeń, który w tłumie pod katedrą, w „nieprzejrzanej ciżbie ludzi”, przeżywał „nie dość dobrze rozumianą wzniosłość chwili" (Gołubiew, 1962, s. 56):

[...] otóż ta [filomacko-filarecka] tradycja uniwersytecka była ciągle jeszcze żywa, Bóg wie jakimi drogami Poczobutt i Jundziłł przesiąkli do powszechnej świadomości, ale jakoś przesiąkli [...]. Owo powszechne uznawanie przez wilnian uniwersytetu za swój, za o sobiście własny, trudno wytłumaczyć ludziom nie tamtejszym, uważającym podobne opowieści za przesadę, jeśli nie wręcz blagę. [...] W Wilnie tak właśnie było. [...] uniwersytet nie był obcy dla stróża czy przekupki kaziukowej, chociaż przecież żadne z nich nie miało $\mathrm{z}$ uniwersytetem nic do czynienia, nie bardzo wiedziało, czym on jest [...]. [...] to był symbol, rzecz odświętna, splendor całego miasta (Gołubiew, 1962, s. 54).

Dla inteligencji Wilna nastawał czas pracy u podstaw. W wywiadzie z 2 października 1919 roku Ruszczyc, określając charakter pracy, którą powinno się wykonać, mówił: „Musimy we wszystkich obywatelach wyrobić świadomość, że tradycja obowiązuje, a po drugie, że to wszystko należy robić w interesie miasta i jego mieszkańców" (Ruszczyc,

${ }^{16}$ Odwołuję się tu do tytułu pracy D. Lowenthala (Lowenthal, 1991, s. 3).

${ }^{17}$ Stosunek polskiej inteligencji do romantycznej tradycji Wilna, do uniwersytetu z czasów filomackich oparty na silnym emocjonalnym przeżywaniu przeszłości był przedmiotem ironicznej krytyki przeprowadzonej przez J. Baudouin de Courtenay w artykule napisanym w 1920 roku, po zwycięskiej akcji Żeligowskiego. Uczony uważał wówczas, że uniwersytet w Wilnie „był co najmniej przedwczesnym” i sądził, iż jedną z przyczyn „do jego kreowania była ogólna psychologia inteligentów polskich, psychologia o charakterze wybitnie archeologicznym, przeszłościowym. Jest to zabarwiona tęsknotą romantyczną orientacja, zaczerpnięta z cmentarzyska historii, wskrzeszająca nieboszczyków, otoczonych aureolą i nimbem świetnych wspomnień. Pod wpływem tych wspomnień chciano wskrzesić nie tylko Uniwersytet Wileński, ale także Liceum Krzemienieckie" (Baudouin de Courtenay, 1920, s. 6). 
1996, s. 41). Kluczowym postulatem jest tu imperatyw kontynuowania przerwanej tradycji a więc intensywna praca przywracania pamięci czy też uobecniania pamięci kulturowej, jej aktywizacja w życiu społecznym, aktualizacja w tu i teraz miasta oraz uczynienie mieszkańców świadomymi nosicielami kulturowej przeszłości Wilna. Tym zadaniom były podporządkowane działania w mieście, przywracające przestrzeni miejskiej wyrugowaną pamięć kulturową.

\section{Pamięć odzyskiwana (Ruszczycowe działania w mieście)}

Upamiętniający charakter działań w mieście, polegający zarówno na tworzeniu nowych form upamiętniania, jak i na przywracaniu do sfery publicznej zapomnianych śladów i świadectw przeszłości, zasadzał się w dużej mierze na nie zawsze artykułowanym wprost przeświadczeniu o Wilnie jako miejscu kształtowania się różnorakich tożsamości. Współgra ono z współczesnymi koncepcjami miasta jako szczególnej "przestrzeni pamięci"18. Wyjątkowa rola miasta jako "depozytariusza przeszłości” odsłania się na kilku poziomach. Architektura, układ urbanistyczny, siatka ulic, place czy poszczególne miejsca w mieście występują jako materialne nośniki pamięci gwarantujące ocalenie czasu historyczno-kulturowego wpisanego w miejską tkankę. Miasto to również przestrzeń, w której wspólnota upamiętnia istotne dla siebie wydarzenia, postacie, utrwalając je w pomnikach, tablicach, nazewnictwie itp. Ta sfera miasta z oczywistych względów jest szczególnie podatna na historyczne fluktuacje, na zmiany wprowadzane przez dominującą politycznie i symbolicznie $\mathrm{w}$ danym czasie grupę $^{19}$. Z kolei materialność miasta, poszczególne budynki, w których rozgrywały się ważne wydarzenia, mogą „stawiać opór dyskursom dominującym” (Rybicka, 2014, s. 308), albowiem już sama ich obecność nie pozwala zapomnieć o warstwach przeszłości pomijanych w dyskursie oficjalnym, zwłaszcza gdy są miejscem nasyconym wielowarstwową temporalnością.

Wilno roku 1919 z punktu widzenia polskiej inteligencji to przestrzeń pełna znaków kulturowej pamięci, współkształtujących jej tożsamość zarówno zbiorową, jak i indywidualną. Z drugiej strony jest to przestrzeń wciąż naznaczona śladami

${ }^{18} \mathrm{Na}$ temat relacji pamięci i przestrzeni zob. prace P. Nory, E. Rybickiej, K. Kończal (Nora, 2011, ss. 20-27; Rybicka, 2014, ss. 305-310; Kończal, 2014, ss. 229-233).

${ }^{19}$ Spektakularnym wycofaniem się Rosjan z wileńskiej przestrzeni symbolicznej wraz z utratą przez nich politycznej dominacji był demontaż pomnika Katarzyny II w 1915 roku. Tak pisał o tym Czesław Jankowski: „Uciekający z Wilna Rosjanie, podczas gdy armaty niemieckie grzmiały już pod Mejszagołą i pod Trokami, wywieźli posąg, orły oraz podobiznę medalu wybitego ongi na pamiątkę »odzyskania« Litwy, wywieźli nie wiadomo dobrze dokąd, podobno do Moskwy. [...]. Figurę cesarzowej, oderwaną od cokołu, zwalono na wznak do olbrzymiej paki i na potężnym automobilu fortecznym [nieczytelne] zawieziono na kolej" (Jankowski, 1919, s. 548). 
rosyjskiej dominacji, widocznych i w warstwie symbolicznej, i w życiu codziennym miasta $^{20}$. Pamięć nostalgiczna ${ }^{21}$, skłonna do uwznioślania przeszłości, otaczania tego, co minione melancholijną aurą, z pewną troskliwością czy wręcz czułością traktująca nawet najmniejszy ślad przeszłości, w pewnej mierze stanowiła impuls do rozpoczęcia prac nad odzyskiwaniem i zagospodarowywaniem symbolicznej warstwy w mieście. Nostalgiczny rys wileńskiej pamięci zadecydował o rekonstrukcyjnym charakterze prac prowadzonych w uniwersyteckich budynkach, jak również o działaniach w przestrzeni miejskiej zbliżonych do prac archeologicznych: materialne ślady pamięci dotąd ukrywane, przechowywane w bezpiecznych miejscach bądź też zapomniane a odnajdywane przez przypadek, wydobywano i przenoszono do odzyskanej sfery publicznej. W tym czasie uwidoczniła się emocjonalna potrzeba rzeczy dawnych, które potrafiłyby zaspokoić pragnienie kontaktu z materialnym świadectwem minionej wielkości czy z jakimkolwiek autentycznym śladem przeszłości.

Najważniejszym miejscem działań przywracających pamięć w sferze materialnej były budynki uniwersyteckie. Niewątpliwie należały one do tych miejsc Wilna, o których można powiedzieć, że została w nich „skondensowana” pamięć polskiej inteligencji, i w których zakotwiczyła ona swoją kulturową wyobraźnię. Uniwersytet stał się jednym z zasadniczych miejsc tożsamościowych ${ }^{22}$. Trwanie żywej komunikacyjnej pamięci o uczelni ułatwiał fakt, że dbała o nią społeczność o dużym kapitale symbolicznym i kulturowym, i która pomimo powstań, zsyłek, emigracji, wciąż mieszkała in situ: realna więź pomiędzy pamiętającą wspólnotą a miejscem przez nią zamieszkiwanym nie została zerwana. Pamięć kulturowa miała oparcie w materialności, w krajobrazie zmieniającym się powoli, w rytmie „długiego trwania”, oglądanym przez jednostkę na co dzień. Wspólnota i przestrzeń geograficzno-kulturowa trwały w symbiotycznym związku i więź ta wyznaczała ramy dla jednostki zaangażowanej w przywracanie pamięci. Gdy Ferdynand Ruszczyc w 1919 roku uczestniczył w reaktywacji uniwersytetu w Wilnie oraz włączaniu w jego strukturę Wydziału Sztuk Pięknych, to czynił to również jako członek wspólnoty pamiętającej, spadkobierca kulturowej tradycji, który świadomie podjął trud działania na rzecz wspólnego miejsca tożsamościowego. Tożsamościowy charakter uniwersytetu dla polskiej społeczności w Wilnie podkreśla też jedna z zachowanych wypowiedzi artysty: „Nie pozostało w Wilnie śladu dawnej

${ }^{20}$ Opis przekształceń dokonanych przez władze carskie w obrębie uniwersyteckich budynków, wskutek czego zatraciły one swój wyraźny styl architektoniczny, można znaleźć w tekście Ruszczyca (Ruszczyc, 1937, ss. 156-163).

${ }^{21} \mathrm{O}$ roli pamięci nostalgicznej w rewitalizacji miast pisała E. Rewers (Rewers, 2010, ss. 79-89).

${ }^{22} \mathrm{~W}$ okresie zaborów, zwłaszcza po powstaniu styczniowym, rolę panteonu narodowego i „depozytariusza pamięci” pełnił kościół śś. Janów. Pamięć wpisaną w architekturę i topografię miasta wzmacniały też przewodniki po Wilnie, przede wszystkim wydawany kilkakrotnie w drugiej połowie XIX wieku przewodnik Kirkora oraz późniejszy przewodnik Zahorskiego (Kirkor, 1880; Zahorski, b.d.). [Tę ostatnią myśl zawdzięczam Recenzentowi]. 
rezydencji królewskiej, renesansowego Zamku Dolnego. Z gmachów świeckich jedynie w podwórzach Uniwersytetu dźwięczą nuty dawnej świetności - epoki dalekich królów. Uniwersytet - to nasz Wawel Wileński” (Ruszczyc, 1937, s. 163).

Działania Ruszczyca w obrębie zespołu uniwersyteckiego dotyczyły kilku wymiarów. Według jego pomysłów i planów latem 1919 roku przebudowywano wnętrza oraz podwórca uniwersyteckie ${ }^{23}$. Równie ważny był jego wkład w zmiany $\mathrm{w}$ warstwie symbolicznej: artysta zaangażował się w tworzenie nowych toponimów i nadał dziedzińcom uniwersyteckim oraz bardziej okazałym salom nazwy własne. Proces ten po latach opisał Bułhak:

Dziedzińce otrzymują wszystkie chrzest z rąk Ruszczyca, [...]. Więc podwórze główne od Świętego Jana nazwane zostaje dziedzińcem rektora Piotra Skargi, następne, przyległe do tamtego, gdzie są resztki wieży astronomicznej i znaki zodiaku - dziedzińcem Poczobutta [...]. Dalej mają iść dziedzińce Sarbiewskiego, Smuglewicza i Mickiewicza [...]. Salę z kolumnami na pierwszym piętrze, gdzie składało się egzamina maturalne rosyjskie, nazywa Aulą Kolumnową [...]. O piętro wyżej znajduje się sala, w której mieściła się cerkiew gimnazjalna [...]. Tej przypisuje imiona Jana i Jędrzeja Śniadeckich $[\ldots]^{24}$.

Ruszczycowy koncept toponimiczny o dużym ładunku kreacyjnym, w pewnym sensie pokrewny biblijnemu aktowi nadawania imion i braniem w symboliczne władanie, był jednocześnie swoistym aktem wpisywania pamięci kulturowej w utworzone przez siebie toponimy. Upamiętniały one wybitne osobowości, a jednocześnie przywoływały okresy rozkwitu uczelni. Stały się więc „Zwiniętą” opowieścią o przeszłości wszechnicy wileńskiej, którą można rozwijać, wędrując z dziedzińca na dziedziniec. Wędrówka ma początek w ustalonym miejscu, na dziedzińcu Piotra Skargi, którego toponim „mieści” w sobie opowieść o początkach wileńskiej uczelni. Nazwy kolejnych dziedzińców Sarbiewskiego, Poczobutta, Mickiewicza - są niczym kolejne rozdziały tej opowieści: od pierwszych dziesięcioleci funkcjonowania wileńskiej wszechnicy, przez reformę nauczania w duchu nowoczesności, czego wyrazem było powstanie obserwatorium astronomicznego, po okres świetności w pierwszej ćwierci XIX wieku. Toponimy wpisane w zespół uniwersyteckich gmachów stały się trwałym nośnikiem pamięci kulturowej, odpornym nawet na dziejowe burze i ideologiczne zafałszowania drugiej połowy XX wieku. Nadanie u początku funkcjonowania USB odimiennych nazw

${ }^{23}$ Kierownikiem prac remontowych i rekonstrukcyjnych uniwersyteckich budynków został inż. Bolesław Stankiewicz, Ruszczyc sprawował pieczę artystyczną: dbał, by całość uzyskała jednolity architektonicznie i artystycznie charakter. Szczegółową informację o przebiegu prac można znaleźć w tekstach Ruszczyca, jak również w Sprawozdaniu Komitetu Wykonawczego Odbudowy Uniwersytetu Wileńskiego („Pierwszy okres prac organizacyjnych”, 1929, s. 47; Ruszczyc, 1937, ss. 156-163).

${ }^{24}$ Co ciekawe, w przytoczonych powyżej wspomnieniach Bułhaka dochodzi do kontaminacji różnych form pamięci: indywidualnej pamięci fotografa, który pamięta te gmachy jako budynki rosyjskiego gimnazjum, pamięci kulturowej niosącej w sobie wiedzę o całej historii uniwersytetu oraz kreacyjny a jednocześnie upamiętniający akt Ruszczyca (Bułhak, 1939, ss. 190-192). 
dziedzińcom budowało poczucie trwałości tradycji, wręcz jej niezniszczalności, przywracało ciągłość „między dawnymi a obecnymi laty”.

Odzyskaniu a następnie zagospodarowywaniu w 1919 roku pouniwersyteckich gmachów towarzyszyło poszukiwanie materialnych śladów przeszłości, przede wszystkim w miejscach przechowujących zazwyczaj rzeczy zużyte, zbędne albo zapomniane pamiątki historyczne, jak piwnice, strychy, zakamarki. W dyskursie memoratywnym mają one podwójny status: przynależą do grupy „przestrzennych” metafor pamięci, ale są też konkretnymi miejscami niejako użyczającymi schronienia wygnanym ze sfery publicznej treściom pamięci kulturowej bądź jej nośnikom. Umożliwiają przechowanie w uśpieniu, w szczęśliwym zapomnieniu zagrożonych zniszczeniem pamiątek, które w zmienionej sytuacji historycznej zaczynają pełnić funkcję świadectw potwierdzających prawo społeczności do dysponowania danym miejscem. Wraz z polityczno-historycznymi zmianami wyrugowane ze sfery publicznej pamiątki, a ocalałe pomimo różnorakich zagrożeń, wracały na dawne miejsca. Status wręcz nieocenionego skarbu mógł uzyskać każdy materialny fragment przeszłości, zwłaszcza gdy zachowany stan pozwalał przywrócić go do kulturowego i społecznego życia i wkomponować w tkankę miasta. Do rangi ważnego wydarzenia urosło znalezienie w trakcie prac restauracyjnych oryginalnej tablicy z napisem: „Academia et Universitas Societatis Jesu"25. Wmurowano ją w ścianę pod posągiem Matki Boskiej, przechowywanym od zamknięcia uniwersytetu w kościele śś. Janów, a w roku 1919 ustawionym ponownie w miejscu „widniejącym na sztychu Wilczyńskiego" ${ }^{26}$. Odnalezione materialne ślady przeszłości mogły powrócić na dawne miejsce dzięki zachowanej ikonografii, a więc zasobom pamięci kulturowej.

Wszystkie prace planowane i wykonywane wówczas przez Ruszczyca czy to w przestrzeni uniwersyteckiej, czy w postaci projektów i rysunków ${ }^{27}$, podporządkowane były kategorii piękna. Jednak pojęcie to należy rozumieć nie tylko w kategoriach czysto

${ }^{25}$ Informacja o odnalezieniu oryginalnej tablicy pojawia się w ówczesnym dyskursie wielokrotnie, w prasie, we wspomnieniach, w tekstach Ruszczyca („Przed otwarciem Uniwersytetu”, 1919, s. 2; Ruszczyc, 1919, ss. 662-663).

${ }^{26}$ Pisząc o „sztychu Wilczyńskiego”, Bułhak niewątpliwie miał na myśli Album Wileńskie Jana Kazimierza Wilczyńskiego (Bułhak, 1939, s. 199).

${ }^{27}$ Listę prac wykonywanych w tym czasie przez Ruszczyca można znaleźć w poświęconej mu Księdze (zob. Bułhak, 1939, s. 195). Działania przywracające pamięć i upamiętniające były bardziej liczne: m.in. podczas uniwersyteckich uroczystości urządzono wystawę uniwersyteckich pamiątek. W tym czasie rodzi się pomysł Pomnika Wyzwolenia. Chociaż pomysł nie został zrealizowany, to Ruszczycowi udało się jednak rok 1919 upamiętnić. Na ścianie gmachu uniwersyteckiego od ulicy Świętojańskiej umieszczono tablicę według projektu malarza, wykonaną w gipsie przez rzeźbiarza Piotra Hermanowicza. Na tablicy widniał napis: 1578 - 1803 - 1919 UNIWERSYTET STEFANA BATOREGO. Ten rodzaj upamiętnienia zaistniał $\mathrm{w}$ uniwersum symbolicznym narażonym na polityczne i historyczne zmiany. W roku 1940 Ruszczycową tablicę zinterpretowano wyłącznie jako znak polskiej dominacji, a nie upamiętnienie odrodzenia uniwersytetu w roku 1919 i ją zniszczono (por. Ruszczyc, 1996, s. 40). 
estetycznych, ale i w kontekście kulturowej i cywilizacyjnej przynależności Wilna. Artysta nazwał Wilno palimpsestem (Ruszczyc, 1919, ss. 662-663), uznając go za wielowarstwowy tekst kultury. Działanie w przestrzeni miejskiej miało na celu wizualne przekształcanie miasta, nadanie mu pięknej formy zgodnej z jego tradycją i historią. Ruszczyc i wileńska inteligencja tego okresu widzieli Wilno jako część zachodniego kręgu cywilizacyjno-kulturowego, a wszelkie ślady rosyjskiej dominacji, elementy wschodnie jako obcą warstwę na wileńskim palimpseście. To wspólne przekonanie wyartykułował artysta w jednym z wywiadów: „Czas, kiedy Wilno chciano zepchnąć do rzędu gubernialnych miast bez oblicza, minął bezpowrotnie. Wilno powinno zająć miejsce w rzędzie miast o tradycjach i kulturze Zachodu" (Ruszczyc, 1996, s. 41). Kontaminacja pojmowanego zgodnie zasadami estetyki piękna oraz głębokiej pamięci kulturowej sprawiała, że wszystkie przeróbki architektoniczne z okresu zaborów, ingerencja w stylistyczną formę wileńskiej architektury były traktowane nie tylko jako znak obcej dominacji w sferze symbolicznej, ale i jako brzydota. Urzeczywistnienie Ruszczycowych „snów o pięknie” w miejskiej przestrzeni było też pragnieniem polskiej inteligencji, albowiem zapewniało harmonię między poczuciem własnej kulturowej przynależności a miejscem, które się zamieszkiwało ${ }^{28}$.

Rok 1919 był kluczowy dla aktywizacji pamięci kulturowej i jej aktualizacji w Wilnie. Pomimo trwających walk na Wschodzie, nierozstrzygniętej państwowej przynależności miasta, wojennych zniszczeń, gospodarczego kryzysu uniwersytet udało się reaktywować. Ciągłość tradycji została ustanowiona i znalazła wzmocnienie w instytucjach publicznych. Dla polskiej wspólnoty pamiętającej nadszedł czas dobrej pamięci. Pozwalała ona uwolnić się od rozpamiętywania bolesnej przeszłości, zamknięcia się w niszczącym kręgu powtórzeń. Dawała impuls do przekształcania rzeczywistości, do budowania tu i teraz i była warunkiem zachowania równowagi między zobowiązaniem wobec przeszłości a przekształcaniem rzeczywistości dla przyszłości. Dobra pamięć towarzyszyła reaktywacji uniwersytetu: imperatywem działania na rzecz wileńskiej wszechnicy było zobowiązanie wobec tradycji, a jednocześnie troska o przyszłość młodych pokoleń. W kręgu jej życiodajnej mocy pozostawał też Ruszczyc - artysta i człowiek o głęboko uwewnętrznionej tradycji, zaangażowany w pracę u podstaw i uprawiający codzienną krzątaninę w wileńskiej materii.

${ }^{28}$ Dobrą ilustracją wyobrażeń i przekonań wileńskiej inteligencji o Wilnie jako mieście przynależnym do kultury łacińskiej jest fragment przewodnika Czesława Jankowskiego, skądinąd sympatyka idei krajowej: „Pochodzenie swoje, charakter swój, swoją kulturę [...] ma Wilno jakby »wypisane na czole«. Tylko rzucić okiem na Wilno, np. z góry Zamkowej! [...] te prześliczne gotyki, te poważne renesansy, te śmiałe baroki, te powagi pełne neo-klasycyzmy stłoczone w wileńskiej kotlinie [...]. Jakie to wszystko... romańskie! Jak czuć od razu, od pierwszego wejrzenia, że tędy przeciągnęła z południa i z zachodu w kierunku na północ i na wschód wielka romańska kultura [...]” (Jankowski, 1927, ss. 11-12). 


\section{Bibliografia}

Ankersmit, F. (2004). Język a doświadczenie historyczne (S. Sikora, Tłum.). W F. Ankersmit, Narracja, reprezentacja, doświadczenie: Studia z teorii historiografii (E. Domańska, Red. \& wstęp) (ss. 223-246). Kraków: Towarzystwo Autorów i Wydawców Prac Naukowych UNIVERSITAS.

Baudouin de Courtenay, J. (1920). Uniwersytet Wileński. Tydzień Polski, 1920(29), 5-6.

Bułhak, J. (1939). Wiek męski Ferdynanda Ruszczyca. W J. Bułhak (Red.), Ferdynand Ruszczyc: Życie i dzieło: Księga zbiorowa (ss. 47-329). Wilno: Wydana staraniem Komitetu Uczczenia Pamięci Ferdynanda Ruszczyca.

Echa uroczystości uniwersyteckich. (1919). Nasz Kraj, 1919(147), 2.

Gołubiew, A. (1962). Stanisław Kościałkowski (Ze wspomnień). Znak, 1962(1(91)), 46-74.

Halbwachs, M. (2008). Społeczne ramy pamięci (M. Król, Tłum.). Warszawa: Wydawnictwo Naukowe PWN.

Horoszkiewiczówna, W. (1922). Promienisty: Prof. Ludwik Janowski. 18. XI 1921. Alma Mater Vilnensis, 1922(1), 40-43.

Jankowski, C. (1919). Na wileńskim bruku. Tygodnik Illustrowany, 1919(34), 548.

Jankowski, C. (1927). Gościom Wilna ku pamięci. Wilno: Polska Drukarnia Nakładowa „Lux” Ludwika Chomińskiego.

Janowski, L. (1929). Pochwała wszechnicy wileńskiej: Wykład inauguracyjny w odnowionym uniwersytecie Wilna, [wygłoszony] w auli Śniadeckich dnia 13 grudnia 1919 r. Alma Mater Vilnensis, 1929(8), 25-33.

Jegelevičius, S. (1994). Pierwsze próby wskrzeszenia Uniwersytetu Wileńskiego i powstanie Uniwersytetu Stefana Batorego (D. Brodowska, Tłum). Lithuania, 1994(4), 45-49.

Jundziłł, Z. (1958). Z dziejów polskiej myśli politycznej na ziemiach b. W. X. Litewskiego (Wspomnienia wileńskie). W S. Kościałkowski, Z. Jundziłł, K. Okulicz, C. Baudouin de Courtenay Jędrzejewiczowa, W. Wielhorski, X. W. Meysztowicz, Z. Folejewski, W. Kwiatkowski, \& J. Kruszyński, Prace zebrane (ss. 40-85). Londyn: Nakładem Społeczności Akademickiej USB.

Kirkor, A. H. (1880). Przewodnik historyczny po Wilnie i jego okolicach. Wilno: Nakładem i drukiem Józefa Zawadzkiego.

Kończal, K. (2014). Miejsce pamięci. W M. Saryusz-Wolska \& R. Traba (Red.), Modi memorandi: Leksykon kultury pamięci (ss. 229-233). Warszawa: Wydawnictwo Naukowe SCHOLAR.

Kościałkowski, S. (b.d.). Prace o Ludwiku Janowskim. Biblioteka Narodowa w Warszawie (sygn. Rps 7643 III).

Lowenthal, D. (1991). Przeszłość to obcy kraj (I. Grudzińska-Gross \& M. Tański, Tłum.). Res Publica, 1991(3), 6-22.

Mianowski, S. (1995). Świat, który odszedt: Wspomnienia Wilnianina: 1895-1945 (M. z Mianowskich Parczewska \& K. M. Mianowski, Red. \& wybór). Warszawa: Oficyna Wydawnicza Rytm. 
Nora, P. (2011). Między pamięcią a historią: Les lieux de memoire (M. Borowski \& M. Sugiera, Tłum.). Didaskalia, 2011(10), 20-27.

Pierwszy okres prac organizacyjnych nad odbudową Uniwersytetu Wileńskiego (13. XII 1918 r. - 11. X 1919 r.): Sprawozdanie Komitetu Wykonawczego Odbudowy Uniwersytetu Wileńskiego. (1929). W Księga Pamiątkowa ku uczczeniu CCCL rocznicy założenia i X wskrzeszenia Uniwersytetu Wileńskiego: T. 2. Dziesięciolecie 1919-1929 (ss. 33-58). Wilno: Nakładem Uniwersytetu Stefana Batorego. Druk Józefa Zawadzkiego w Wilnie.

Przed otwarciem Uniwersytetu. (1919). Nasz Kraj, 1919(141), 2.

Przemówienie Naczelnika Państwa podczas otwarcia Uniwersytetu 11. X 1919 r. (1919). Nasz Kraj, 1919(146), 1.

Rewers, E. (2010). Spór o przestrzeń kulturową: pamięć nostalgiczna czy pamięć krytyczna? W E. Rewers, Miasto-twórczość: Wykłady krakowskie (ss. 79-89). Kraków: Wydawnictwo WAW.

Romanowski, A. (1999). Młoda Polska wileńska. Kraków: Towarzystwo Autorów i Wydawców Prac Naukowych UNIVERSITAS.

Römer, M. (2018). Dzienniki: T. 3. 1916-1919. Warszawa: Ośrodek Karta.

Rosińska, Z. (2006). Metafory pamięci. W Z. Rosińska (Red.), Pamięć w filozofii XX wieku (ss. 263-278). Warszawa: Wydział Filozofii i Socjologii Uniwersytetu Warszawskiego. Wydawnictwo.

Roszak, S. (2004). Archiwa sarmackiej pamięci: Funkcje i znaczenie rękopiśmiennych ksiag silva rerum w kulturze Rzeczypospolitej XVIII w. Toruń: Wydawnictwo Uniwersytetu Mikołaja Kopernika.

Ruszczyc, F. (1919). Tablice Historyi. Tygodnik Illustrowany, 1919(40-41), 662-663.

Ruszczyc, F. (1937). Liść wawrzynu i płatek róży: Przemówienia, wykłady, odczyty, artykuły w języku polskim i francuskim: Wydanie pośmiertne (J. Bułhak, Red. \& ilustracje). Wilno: Nakładem Stanisława Turskiego.

Ruszczyc, F. (1994). Dziennik: Cz. 1. Ku Wilnu (E. Ruszczyc, Wybór, układ, opracowanie, wstęp \& posłowie). Warszawa: „Secesja”.

Ruszczyc, F. (1996). Dziennik: Cz. 2. W Wilnie (E. Ruszczyc, Wybór, układ, opracowanie, wstęp \& posłowie). Warszawa: „Secesja”.

Rybicka, E. (2014). Pamięć i przestrzeń. W E. Rybicka, Geopoetyka: Przestrzeń i miejsce we współczesnych teoriach i praktykach literackich (ss. 305-310). Kraków: Towarzystwo Autorów i Wydawców Prac Naukowych UNIVERSITAS.

Saryusz-Wolska, M. (2009). Wprowadzenie. W M. Saryusz-Wolska (Red.), Pamięć zbiorowa i kulturowa: Wspótczesna perspektywa niemiecka (ss. 7-38). Kraków: Towarzystwo Autorów i Wydawców Prac Naukowych UNIVERSITAS.

Sukiennicki, W. (1967). Legenda i rzeczywistość: Wspomnienia i uwagi o dwudziestu latach Uniwersytetu Stefana Batorego w Wilnie. Paryż: Instytut Literacki.

Uroczyste otwarcie uniwersytetu. (1919). Nasz Kraj, 1919(145), 9.

Władysławowi Mickiewiczowi w dniu Jego przyjazdu do Wilna składa w hołdzie Redakcja. (1919). Nasz Kraj (Dodatek), 1919(142), 1. 
Wrzosek, A. (1929). Wskrzeszenie Uniwersytetu Wileńskiego w r. 1919. W Księga Pamiątkowa ku uczczeniu CCCL rocznicy założenia i X wskrzeszenia Uniwersytetu Wileńskiego: T. 2. Dziesięciolecie 1919-1929 (ss. 1-32). Wilno: Nakładem Uniwersytetu Stefana Batorego. Druk Józefa Zawadzkiego w Wilnie.

Zahorski, W. (1919-1920). Dziennik dra Władysława Zahorskiego z czasów wojny Europejskiej 1914-1919: T. 4. 19 IV 1919 - 3 IV 1920. Biblioteka Narodowa w Warszawie (sygn. Rps 10457II).

Zahorski, W. (b.d.). Przewodnik po Wilnie. Wilno: Drukarnia Wydawnicza Józefa Zawadzkiego. Zamojska, D. (2006). „Ta ludność życzy mieć uniwersytet ...” - Walka o utworzenie Uniwersytetu Stefana Batorego w Wilnie. Kwartalnik Historii Nauki i Techniki, 51(2), 7-46.

\title{
Rok 1919: pamięć Wilna - pamięć w Wilnie
}

\section{Streszczenie}

W swoim artykule przywołuję wyodrębnione przez współczesnych badaczy trzy formy pamięci: indywidualną, komunikacyjną, kulturową - i traktuję je jako poręczne narzędzie do opisywania zjawiska „cyrkulacji” treści pamięci we wspólnotach pamiętających. Za taką pamiętającą wspólnotę uznaję polską społeczność Wilna, zwłaszcza inteligencję, i ukazuję, w jaki sposób aktywizowały się te trzy formy pamięci w konkretnym czasie historycznym. Stawiam tezę, iż rok 1919 i czas pracy nad wskrzeszeniem uniwersytetu był kluczowy dla przeniesienia treści pamięci komunikacyjnej, zwłaszcza jej postaci rodzinnej, do pamięci kulturowej.

Prace nad wskrzeszeniem uniwersytetu łączyły się bezpośrednio z przywracaniem pamięci kulturowej w przestrzeni miasta. Zasadniczą rolę w tym procesie odegrał Ferdynand Ruszczyc jako artystyczny opiekun prac rewitalizacyjnych gmachów uniwersyteckich, autor toponimów i kluczowa postać ówczesnej kultury wileńskiej.

Słowa kluczowe: Uniwersytet Stefana Batorego; Ferdynand Ruszczyc; pamięć indywidualna; pamięć rodzinna; pamięć kulturowa

\section{9: Memory of Vilnius - memory in Vilnius}

\begin{abstract}
This article applies the framework of three types of memory - individual, communicative and cultural - as an effective tool for describing the phenomenon of "circulation" of the content of memory in communities of memory. I approach the Polish community
\end{abstract}


in Vilnius, especially the intelligentsia, as a community of memory, and show how the three forms of memory were activated at a particular historical time. I argue that the year 1919 and the time of reviving Vilnius University was crucial for the transfer of the content of communicative memory in general, and family memory in particular, to cultural memory. The effort to revive the university was directly related to the restoration of cultural memory in the urban landscape of Vilnius. The person who played the main role in this process was Ferdynand Ruszczyc, the artistic supervisor of revitalisation of university buildings, the author of toponyms and the key figure of cultural life of the city at the time.

Keywords: Stefan Batory University; Ferdynand Ruszczyc; individual memory; family memory; cultural memory

Dr Walentyna Krupowies is a lecturer at the Institute of Polish Philology and Modern Languages at the Siedlce University of Natural Sciences and Humanities. She graduated from the Universities of Vilnius and Warsaw. She holds a $\mathrm{PhD}$ from the University of Warsaw and is the author of about thirty articles, studies and reviews published in Poland and Lithuania, and a co-editor of three multi-author monographs. Her research interests include literature of the former North-Eastern Borderlands (Kresy), late works by Czesław Miłosz, urban issues in literature, and Vilnius culture of the interwar period.

Bibliography (selected): Podróż na Wschód. Rosja w tekstach Miłosza [A journey to the East: Russia in the writings of Czesław Miłosz], in: W kręgu idei Miłoszowskich, Vilnius 2011, 125-137; Wędrówki i przechadzki po Wilnie dwudziestolecia międzywojennego [Wandering and strolling around interwar Vilnius], Przegląd Humanistyczny 6, Warszawa (Warsaw) 2014, 125-137; Czas podróży korzennych [The time of journeys to the roots], Konteksty. Polska Sztuka Ludowa 4, Warszawa (Warsaw) 2015, 132-138; Prawda literatury faktu a prawda literatury świadectwa (Chaim Grade - Józef Mackiewicz - Czesław Miłosz) [The truth of non-fiction literature and the truth of a literary witness (Chaim Grade - Józef Mackiewicz - Czesław Miłosz)], Conversatoria Litteraria 10, Siedlce, Banská Bystrica 2016, 345-359.

Correspondence: Walentyna Krupowies, Institute of Polish Philology and Modern Languages, Siedlce University of Natural Sciences and Humanities, Siedlce, e-mail: vakru@onet.eu

Support of the work: The study was conducted at the author's own expense.

Competing interests: No competing interests have been declared. 